\title{
Te Rito Toi in New Zealand: A Caring Response to the Pandemic
}

\author{
Peter O'Connor and Marta Estellés* \\ Centre for Arts and Social Transformation, The University of Auckland, Auckland, New Zealand
}

Te Rito Toi is an online open access educational resource designed to help teachers respond to the extraordinary circumstances of the pandemic and provide all children with opportunities to engage with the arts. Central to the Te Rito Toi project was the concept of well-being, one of the United Nations Sustainable Development Goals (SGD 3). The study reported in this article delved into the perspectives of a group of New Zealand educators who used Te Rito Toi after the Covid-19 lockdown to explore the ways in which this resource helped them to engage their students in both individual and collective recovery. The analysis of the interviews revealed the following four themes: 1) building relationships and a sense of belonging; 2) enhancing communication and empathy; 3) connecting with wider social issues; and 4) contributing to community recovery.

Keywords: arts-based pedagogies, care, COVID-19 lockdown, schools, New Zealand

\section{OPEN ACCESS}

Edited by:

Cecilia Latorre-Cosculluela, University of Zaragoza, Spain

Reviewed by:

Dolana Mogadime, Brock University, Canada Angela Page,

The University of Newcastle, Australia

*Correspondence: Marta Estellés marta.estelles@auckland.ac.nz

Specialty section: This article was submitted to Educational Psychology, a section of the journal

Frontiers in Education

Received: 31 July 2021 Accepted: 16 September 2021 Published: 14 October 2021

Citation:

O'Connor $P$ and Estellés $M$ (2021) Te Rito Toi in New Zealand: A Caring

Response to the Pandemic. Front. Educ. 6:750905. doi: 10.3389/feduc.2021.750905

\section{INTRODUCTION}

Te Rito Toi, an arts-based educational resource developed during the 2020 Covid-19 lockdown in New Zealand, was designed to support teachers and principals as schools reopened (O’Connor and Estellés, 2021; van Lieshout, 2020). At the centre of the project was a recognition that a focus on well-being through relationship building and community recovery was essential before schools could re-engage with the formal curriculum (e.g., O'Connor, 2013a; Mutch, 2020b). In many ways, this approach mirrored the broader governmental and social response to the pandemic, characterised by an approach centered around manakitanga. Manaakitanga is a term that is impossible to translate directly into English, its true meanings are deeply embedded in Māori culture. It is, however, commonly understood in New Zealand as having at its heart the idea that communal well-being has importance equal to, and even greater than, one's own. The concept is disarmingly simple. In contrast to the Global North which celebrates the individual, manaakitanga privileges the collective. The term springs from the Māori word "mana," which is the spiritual life force and energy that every living thing possesses. Manaakitanga recognises that freedom as an individual is only as strong as your place in the community. The bicultural writing pair (one Mãori and one non-Māori) Mathew Milner and Ngata (2021) argue that this approach underpins many aspects of life in New Zealand beyond Indigenous communities:

We provide health care to anyone who needs it. Our gun safety laws focus on keeping the community safe. And manaakitanga is one of four key values the Teachers Council for New Zealand wants teachers to focus on in the classroom (p.)

They suggest manaakitanga defines more than anything the reason behind New Zealand's extraordinary success in managing the Covid-19 pandemic.

This deep-seated cultural practice saw New Zealanders embrace one of the world's strictest lockdowns as part of what the Prime Minister, Jacinda Ardern, referred to as "the team of five million", not for themselves but for others. The Māori proverb "He waka eke noa" expresses these 
sentiments clearly: the literal translation is that "we are all in the same canoe", which might be more colloquially expressed as "we are all in this together".

When schools reopened after the lockdowns in New Zealand, perhaps it is not surprising that schools were encouraged to focus on well-being in the wider sense of ensuring all were cared for. Te Rito Toi led the return for many by placing the arts and wellbeing at the heart of learning. This article reports on a participatory research study with eight schools that used $\mathrm{Te}$ Rito Toi as an integral approach to reopening classrooms.

\section{LITERATURE REVIEW: THE ARTS IN POST-CRISIS CONTEXTS}

Using the arts to help children and young people in post-crisis contexts has become increasingly recognised by research literature, especially during the Covid-19 pandemic (e.g., Cziboly and Bethlenfalvy, 2020; Tam, 2020; Davis and Phillips, 2021). Over the last decade, studies have highlighted the potentiality of arts-based activities to critically and emotionally process major events (e.g.,O'Connor, 2013a; Fenner et al., 2018; Murphy, 2014; Mutch and Latai, 2019). As verbal expression can be restricted by language development or emotional pain for children and young people, the arts provide alternative pathways to express thoughts and emotions and make sense of the circumstances surrounding them. As Mitchell (2015) noted in her work, "some children strained to express their emotions and traumatic memories verbally, but on paper, where anything was fair game, they vividly, graphically showed their experiences in drawings" (p. 191). Using non-verbal arts in the recovery process can also extend the ability to self-express in culturally specific ways by bridging cultural prohibitions and illuminating the feelings and experiences that frequently remain silent (Fenner et al., 2018). Studies have also found that using arts-based activities after critical or life-changing events increases feelings of hope in the future (e.g., O'Connor and Takahashi, 2014; Murphy, 2014; Mutch and Latai, 2019).

However, arts-based educational programmes in post-crisis contexts benefit children and young people not only individually, but also collectively. The international literature review on the impact of the arts on health and well-being conducted by Bidwell (2014) found that the arts help reduce isolation, build relationships, strengthen social support and create social cohesion (p. 6). Arts-based educational programmes provide children with the opportunity to share their experiences and feelings with peers, finding empathy and commonality and, rebuilding a sense of community (Huss et al., 2016; Fenner et al., 2018; Mutch and Latai, 2019). In addition, as an increasing number of scholars have recently noted, young people in post-disaster contexts highly value activities where they can be involved in the recovery process and contribute to restoring collective hope in the future (O'Connor and Takahashi, 2014; Mutch, 2013; Peek et al., 2016; Peek, 2008).

Despite these positive results, arts-based programmes are not always taken into serious consideration in educational contexts after major events. Unfortunately, the "going back to normal" approach has frequently dominated the logic behind reopening schools (O'Connor, 2013a), ignoring the importance of devoting time to creatively and collectively explore and process the crisis. Often, only selected groups of children are offered the opportunity, which should be available to all affected children, of creatively making sense of the crisis (Gibbs et al., 2017). The arts as well-being enhancers have traditionally been underrecognised, under-resourced and under-researched (Walls et al., 2016), remaining as a privilege for a few.

Since the pandemic started, several studies have warned about the consequences of lockdowns on children and young people's mental health and well-being (e.g., Courtney et al., 2020; Golberstein et al., 2020), reporting higher levels of anxiety and depression (Courtney et al., 2020; Shanahan et al., 2020), physical exhaustion and low motivation (Labrague and Ballad, 2020), uncertainty about the future ( $\mathrm{Li}$ et al., 2020), poor sleeping and dietary habits and fear of infection (Ghosh et al., 2020). The isolating circumstances generated by lockdowns have also been a challenge for teachers, who have seen themselves immersed in increasingly individualistic professional cultures (Hargreaves and Fullan, 2020), dealing with considerable work overload (e.g., Rio-Poncela et al., 2021; Ozamiz-Etxebarria et al., 2021). While lockdowns have been an opportunity to develop and explore the possibilities of distance learning models (e.g. Gallagher et al., 2020; Skregelid, 2021), both teachers and students from all over the world have mentioned missing the social aspect of learning during this period (Mutch and Estellés, 2021; Rio-Poncela et al., 2021; OECD, 2020). In response, several scholars and educators have claimed that using the arts in educational contexts nurtures human relations during these disruptive times (e.g., Gallagher et al., 2020; Tam, 2020; Davis and Phillips, 2021). As they noted, the social, relational and embodied aspects of learning, sometimes called the "nonacademic" or "invisible" outcomes of education (Martin et al., 2013; Davies and Phillips, 2021), missing during lockdowns are the ones most specifically promoted by arts-based pedagogies.

\section{BACKGROUND: TE RITO TOI IN NEW ZEALAND}

When New Zealand went into a strict 7-week lockdown in March 2020, a team at the University of Auckland created a set of open access educational resources under the name of Te Rito Toi. The team consisted of Indigenous and non-Indigenous scholars preparing resources that privileged local stories and knowledge systems. The phrase Te Rito Toi was gifted to the project by Michael Steedman-Ngāti Whātua o Ōrākei, Ngāti Whātua, Te Uri o Hau Kaiarataki, pro Vice Chancellor Maori for the University of Auckland. In gifting the name, he endorsed an approach centred in manaakitanga. Te Rito Toi is a metaphor that relates to the harakeke bush (a New Zealand native plant used for multiple purposes in traditional and contemporary Māori society). The rito is the seedling at the centre of the plant protected by wide leaves. Without this care and protection not only does the seedling die but so does the whole plant. Nga toi can be translated as the arts, although that too is not a full translation. 
However, the phrase might conjure up ideas that it is the arts that protect and care for the mana of the rito, or that the arts need to be cared for if the rito is to flourish. It is a complex metaphor that is steeped in Māori cosmology and was a generous gift to the project. The gift of the name in te reo (Māori language) also ensured a steady and strong uptake of the resource in schools with large numbers of Māori students. Part of the commitment embedded in the name gifting was to produce resources in the Māori language for schools where te reo is the language of instruction and the writing of these resources was carried out by Indigenous scholars.

The aim of Te Rito Toi was to help primary teachers respond to the extraordinary circumstances of the pandemic and provide all children with rich opportunities to engage with the arts. The resources were based on extensive research in schools postdisaster conducted by the team (see Gibbs et al., 2013, O'Connor and Takahashi, 2013a; O'Connor and Takahashi, 2013b; Mutch, 2013; Mutch, 2014; Mutch, 2020a). This research has systematically highlighted the importance of schools acting as caring communities in post-disaster recovery, helping children reconnect with their peers, share their life experiences and make sense of the outside world.

Central to the Te Rito Toi project was the concept of wellbeing, which is one of the United Nations Sustainable Development Goals (SGD 3). This concept, however, is often defined in narrow, individualised and neoliberalised ways, becoming synonymous with personal fulfillment within a "global happiness industry" (Freebody et al., p. 140). In post-disaster settings, the idea of well-being usually translates into making children more resilient to challenging environments, focusing therefore on self-care and responsibility (Freebody et al., 2018). Thus, the individual is presented as the problem in need of intervention (Walls et al., 2019). In this project, however, we embraced a more holistic understanding of the term "well-being" (Dunphy, 2015) in which the relational, social and civic dimensions of arts engagement become paramount. We chose an approach centred around manaakitanga, providing resources for teachers to create opportunities for pleasure, emotional safety and self-expression that are intrinsically linked to experiences of social reconnection, caring for others and community engagement. This approach is based on a notion of care as "inter-relational" (Trnka and Trundle, 2014), which is "constituted through the dual aspects of recognition and action motivated by one's commitment to the welfare of the other" (p. 142). This approach also aligns with the recognition of children's rights and capacity to contribute to the matters affecting their lives, stated by the United Nations Convention on the Rights of the Child (United Nations Convention on the Rights of the Child, 1989). Much of post-disaster interventions with children have been driven by the children at risk discourse, which reflected a view of children as passive victims in critical contexts (Mutch, 2013). This idea, however, has been increasingly challenged by research showing children's capacity to contribute to community recovery and the mental health benefits of this involvement (Anderson, 2005; Peek, 2008; Peek et al., 2016; Gibbs et al., 2017), proving the juxtaposition between children's protection and participation to be false (Warrington \& Larkins, 2019).

The resources contained in Te Rito Toi took different mediums of expression (drama, dance, poetry, etc.) to offer pathways for children to interrelatedly express their voices, process their emotions and engage with the wider community.

The team of writers working on Te Rito Toi created a set of lesson plans focused on well-being from the above-explained holistic perspective of well-being. Arts education experts, Professor Julie Dunn and Professor John O’Toole from Australia, adapted materials to provide rich drama lessons that give young children the opportunity to collaboratively (re) consider how communities respond in crises or fear and the consequences of social regulation. The Poutokomanawa, a collective group of Indigenous writers, created the Hā Ora (breath of life) resource centred around the use of Māori art forms that blend music, dance, theatre and visual arts together to re-engage children within the classroom. The set of picture books created by Professor Carol Mutch about a toy bear in lockdown provided a narrative setting for children to effectively explore the lockdown experience and make sense of the pandemic. New Zealand Poet Laureate, Associate Professor Selina Tusitala Marsh, created a poetry lesson plan to celebrate the capacity to be an everyday hero. Ginnie Thorner, a drama teacher who worked extensively in schools after Christchurch's earthquakes, provided dance and visual arts lessons that focused on making sense of social distancing [Author] contributed with the lesson plan "Teaspoon of Light" that used the arts to repair dreams and restore collective hope in the future. These resources constituted the first substantial curriculum resources in the arts and well-being for New Zealand primary schools in at least 15 years.

Te Rito Toi was launched in April 2020 as schools in New Zealand prepared to reopen. As part of the project, a series of webinars about the use of the arts and well-being were offered to introduce the resources. These webinars attracted over 30,000 teachers in Australia and New Zealand and the website had over 250,000 pageviews only in the first month of it being online. These numbers suggest an extraordinary demand for meaningful classroom support on the arts and wellbeing for teachers post-crises. The international recognition gained from UNESCO, the World Alliance of Arts Educators and the OECD (see van Lieshout, 2020) indicates that this demand has not been unique to Australia and New Zealand.

In this article, we delve into the perspectives of a group of educators, who used Te Rito Toi after the Covid-19 lockdown in New Zealand, to explore the possibilities and limitations offered by this resource to interrelatedly promote individual and collective recovery.

\section{METHODOLOGY AND METHODS}

The data for this article comes from a larger qualitative study on how New Zealand schools responded to the pandemic and used the Te Rito Toi resources when classes resumed after the Covid19 lockdowns. The project, funded by UNESCO, Cognition 
TABLE 1 | Characteristics of the schools.

\begin{tabular}{|c|c|c|c|c|c|c|c|c|}
\hline $\begin{array}{l}\text { School } \\
\text { characteristics }\end{array}$ & $\begin{array}{c}\text { School } \\
1\end{array}$ & $\begin{array}{c}\text { School } \\
2\end{array}$ & $\begin{array}{c}\text { School } \\
3\end{array}$ & $\begin{array}{c}\text { School } \\
4\end{array}$ & $\begin{array}{c}\text { School } \\
5\end{array}$ & $\begin{array}{c}\text { School } \\
6\end{array}$ & $\begin{array}{c}\text { School } \\
7\end{array}$ & $\begin{array}{c}\text { School } \\
8\end{array}$ \\
\hline Location & Large city & Large city & Large city & Large city & $\begin{array}{l}\text { Regional } \\
\text { city }\end{array}$ & Regional city & Large city & Small town \\
\hline School type & $\begin{array}{l}\text { State } \\
\text { integrated }\end{array}$ & State co-ed & $\begin{array}{l}\text { State } \\
\text { co-ed }\end{array}$ & State co-ed & State co-ed & State co-ed & State co-ed & State integrated \\
\hline SES & Low & High & Low & High & High & High & Medium & High \\
\hline \multirow[t]{5}{*}{$\begin{array}{l}\text { Ethnic profile of the } \\
\text { school }\end{array}$} & Māori 4\% & Māori 4\% & Māori 10\% & Māori 4\% & Māori & $\begin{array}{l}\text { Māori and } \\
\text { Pacific 15\% }\end{array}$ & Māori 23\% & Māori 16\% \\
\hline & Pacific 90\% & $\mathrm{NZ}$ & Pacific & $N Z$ & $8 \%$ & NZ European 77\% & NZ & $\mathrm{NZ}$ \\
\hline & & European 68\% & $66 \%$ & European 78\% & & & European 18\% & European 57\% \\
\hline & Other & Chinese 9\% & $\begin{array}{l}\text { Indian } \\
10 \%\end{array}$ & Asian 16\% & $\begin{array}{l}\text { NZ } \\
\text { European }\end{array}$ & Asian 8\% & Pacific 41\% & Pacific 8\% \\
\hline & $6 \%$ & $\begin{array}{l}\text { Indian 8\% } \\
\text { Pacific 8\% } \\
\text { Other 3\% }\end{array}$ & Other 14\% & Pacific 2\% & $\begin{array}{l}64 \% \\
\text { Pacific } \\
4 \% \\
\text { Asian } \\
17 \% \\
\text { Other } 7 \%\end{array}$ & & Other 18\% & $\begin{array}{l}\text { Chinese } 4 \% \\
\text { Other } 15 \%\end{array}$ \\
\hline
\end{tabular}

Source: Own elaboration based on data from the Education Review Office website.

Education Trust and The University of Auckland, took place between April 2020 and February 2021. Based on previous participatory research experiences in post-disaster settings (Mutch et al., 2015), a participatory research study was undertaken with eight primary schools across New Zealand that used the Te Rito Toi resources when returning to school after the Covid-19 lockdowns. As can be seen in Table 1, the schools were part of considerably different socio-economic and ethnic communities. A constructivist theoretical framework (Burr, 2015) underpinned this study, in which the researchers and participants co-constructed each school's experience, prior to the cross-case analysis (Charmaz, 2014) conducted by the research team. Each school negotiated the process, participants and data collection concerning their own school.

The participants involved in the study varied from school to school, yet usually included the principal and a selection of team leaders and teachers. This article draws from 15 semi-structured interview transcripts where principals and teachers spoke specifically about their educational experience during the Covid-19 crisis and their use of Te Rito Toi after the Covid-19 lockdowns. The interviews were audio-recorded, transcribed in full and revised by the participants.

A constant comparative method (Charmaz, 2014; Mutch, 2013) was used to analyse the data. The interviews from each school were independently examined for codes, categories, concepts and themes, prior to being compared and contrasted horizontally (across all schools) and vertically (within each theme). In this article, we focus on the four themes that emerged from the Te Rito Toi related data set: 1) building relationships and a sense of belonging; 2) enhancing communication and empathy; 3) connecting with wider social issues; and 4) contributing to community recovery.

Ethical considerations were carefully contemplated from the beginning and included informed consent, right to withdraw, anonymity, and confidentiality. Before the fieldwork began, the research team obtained the ethical approval of The University of Auckland Human Participants Ethics Committee (Ref. 2816).

\section{FINDINGS}

\section{Building Relationships and a Sense of Belonging}

One of the main reasons why the educators involved in this study used Te Rito Toi was to reconnect students after the isolating circumstances created by lockdowns and to rebuild a sense of community. They recognized that they simply could not return to school as if nothing had ever happened and highlighted the need to "take time to bring children back together". For these educators, the arts provided a rich opportunity to achieve this aim. They resorted to Te Rito Toi because they were determined to put relationships at the core of school life. As the following principal explained to us:

when the children came back, one of the things they said was that they missed their social learning with each other and being together. And coming back to school wasn't just about seeing each other and being friends, but actually doing the things that we do at the school that required us to be together with each other. And that was where the whole kind of approach that we have and the approach with Te Rito Toi, the idea that, you know, that the drama pedagogy in particular brings together a whole lot of different things under one umbrella. And so the idea was when the children come to school, we want to actually make the programme rich. We're going to cut down and make it kind of, like, simple. We want to give them the kind of challenges and things that they would do, which show them the point of school, which is school is about being together. 
With the goal of "bringing children back together" in mind, three of the principals that participated in this study encouraged the use of Te Rito Toi during the first staff meeting after lockdowns. The following principal whose school was located in the neighbourhood where the biggest Covid-19 outbreak in the country took place talked about the importance of providing spaces for pleasure, dialogue and relationship building during this time. For this principal, Te Rito Toi helped to create this space allowing children's worries and fears to emerge. As this principal said in the interview:

In one of our touch base sessions with all of the staff, we talked about it [Te Rito Toi] because the focus was on well-being and we were looking for things around wellbeing and creativity. So teachers just began to use it and [...] the teachers were using the resources from Te Rito Toi to actually bring the children back and to get them to talk about what it had been like [being in lockdown], they were listening to these stories because we had some kids who were really worried that their parents were going to die. [...] And it was really, just when people came back after the first lockdown, I just see it, you know, just have fun with our kids. And, you know, take the time and take the time for the conversation. So Te Rito Toi was a great springboard for that.

The teachers that participated in this study also provided examples of how the arts and Te Rito Toi helped them work towards creating a sense of community and building relationships. For the following teacher, a sign that the Te Rito Toi resources nurtured relationships was the children's refusal to use their computers afterwards. In her interview, she reproduced the following dialogue with her students about the reason behind this situation:

It was just interesting when they didn't want to go back to their computers [...] And I think I said to the children: "Why do you think we are not using our computers?" And some of the responses were really intriguing [... ] because we're talking with each other, we're having fun, you know, we're talking in groups and we're discussing. And they had it all. And I said: "That is why we've dropped the computers. [...] It was to build your relationships." And so, they actually realised: "Wow, this is a really good, you know, good thing what we've done just to get back, build relationships, talk with each other, you know, get back into society a little bit more."

Another teacher highlighted that Te Rito Toi helped students in her class to create a sense of community, build caring relationships and break barriers and stereotypes between girls and boys. As she explained to us in the interview:

It did help to build relationships. We are intermediate so you've got puberty kicking in, and very much an awareness of boys and girls and, you know, sort of being a little bit shy amongst each other or being a little bit silly. And they got to the stage where they actually all really cared about each other and they were very happy to support each other, even if it was in a sort of a roundabout way. Yeah, it definitely helped with relationships and they did have a sense of identity as a team.

For the following teacher, Te Rito Toi took the students out of their routines and promoted different dynamics within existing relationships. As she explained to us in the following quote, one of the drama processes contained in Te Rito Toi contributed to the change in roles and dynamics within her class:

We've sort of got 12- and 13-year-old boys where it's not cool to do anything that's not with a soccer ball or something. One boy who was particularly interested in doing drama, and he wanted to try and the rest of the group was all girls. He joined a little bit later than the girls started. He got two of his mates, and he made them come along with him and so we had three boys. This just added a different dynamic because he was the leader with those boys, the other boys came along and because he was very cool, they took part. So, it was really interesting, and he was awesome to work with because he wanted to be there. I took a photograph once when they were decorating the dream cloth and putting all the dreams on the dream cloth, all three of these boys had their arms intertwined, like one person's drawing here and the other arms here and they're completely intertwined, working together and it was just gorgeous.

\section{Enhancing Communication and Empathy}

Another recurring theme in the interviews was the idea that $\mathrm{Te}$ Rito Toi was an opportunity for students' (emotional) selfexpression. The majority of the participants recognised that $\mathrm{Te}$ Rito Toi provided a space where students could express their feelings and share their life experiences during lockdowns. For the students of the following teacher, the "My-Why poem" found in Te Rito Toi, a poetry exercise aimed at helping students creatively explore their own "why", provided a space for self-exploration and expression. In particular, this poem allowed lockdownrelated feelings and experiences to arise. As this educator explained to us:

The big thing with "My-Why poem" was that they didn't realise but they were talking about themselves, and they were bringing in their feelings and anxieties during lockdown. When I looked back at it, you can see how they're feeling during lockdown, you know, the feelings and thoughts during lockdown.

The exercise of self-expression triggered by the resources usually led to a process of connection with one another. As the following teacher explained to us, Te Rito Toi facilitated her 
students' discovery of shared emotions and experiences, which in turn helped them to relate and sympathise with each other. See, for example, the following quote:

I just know that the whole group appreciated having the opportunity to share how they were feeling and, in particular, using their emotions and putting them into body actions [with the drama]. Yeah, they could relate. And I think as well that, even though the drawing doesn't help them to kind of regroup as such, it was great to share it with their friends and the conversations that they had with each other were really valuable [...] they've all gone through a similar experience, they relate, you know, even though their experience was slightly differently because of their own families.

The resources, however, not only elicited conversations about Covid-related worries and experiences, but also about other ongoing anxieties and fears. For the following teacher, Te Rito Toi prompted conversations about students' concerns that, although exacerbated by the Covid-19, moved beyond the pandemic:

I think the kids took risks by being vulnerable, by talking about some of their bad dreams. [...] There were some children who were anxious about Covid, but for many of them, it was lots of different things, things that I wouldn't have predicted like "my best friend moves school and I don't have my best friend anymore" and things like that, not necessarily something really, really big, like a pandemic. But there were some who would say things like, "I don't want my mom to get sick" or "I'm worried about getting sick". But then we say getting sick, they didn't necessarily mean with Covid, some kids mentioned cancer, some kids mentioned other illnesses. So I don't know if perhaps, pandemic and all the pandemic talk, maybe exacerbated some of those worries. But it also shows that just because we're in a pandemic doesn't mean that other worries aren't here.

This teacher, who works in a school located in a low-income area, also recognised the limitations of Te Rito Toi to deal with issues related to poverty. As she suggested during the interview:

It'd be really cool to have some things in there [Te Rito Toi] that deal with how children cope with poverty, because that is an everyday trauma that a lot of children are going through unfortunately. And, as a country, we all want that to not be the case. But it is the case. And it would be, I think, incredible to have resources that reflect that. Because those are a lot of children's experiences of trauma.

\section{Connecting With Wider Social Issues}

One of the possibilities of the Te Rito Toi resources noted by the participants was its ability to connect with wider social issues. Most resources did not mention the words "pandemic", "lockdown" or "Covid-19", nor any other social issues, but the fictional worlds and metaphors they created allowed for multiple connections, with both individual and collective experiences. As one of the teachers said:

I didn't have to connect it [with Covid], the children connected it up [...] they found the connections very, very easily. They actually related it to the online connections, bullying. ... And they were even relating that to their feelings of the online journey during Covid.

For some of the educators that participated in this study, these connections were at the core of their pedagogical experiences with Te Rito Toi. The following principal explained to us that the "Regulating robot", a drama resource about the design and programming of a robot, elicited discussions and social dilemmas about the management of the pandemic and child labour conditions in the past:

With the "Regulating robot", it became less about the robot and just this place where the kids could actually talk about questions and issues around Covid, before they went into making their dramas. So, in the end, one group of children did a play, made up a drama, made up a kind of series of dramas, and eventually turned it into a performance around child labour in the 19th century in Otago, and the kind of oppression and rules that the children are forced to live under. And can you see how that indirectly goes back to the "Regulating robot?" [...] the children started a discussion about: "Here we are in this constrained situation, where there are all these rules that operate under [Covid-19] Level 4 and Level 3." Then, you think: "Well, if children are working in a factory, you know, they are not free, they're not like us, they can't do what they want with their normal lives, there are all these rules and conditions that the boss says, and they're basically not like children, they don't have school." So, you see, it's a kind of an extension of their experience already into a fictional world, which of course, is what process drama is all about.

Some teachers also highlighted the connection that the students made between the Te Rito Toi resources and the Black Lives Matter protests that were taking place at that moment. The "Green children" lesson plan, a drama about two green children who suddenly turn up in a small town, was particularly fruitful in this regard. As one of the participants said, "They were having philosophical discussions around things like racism and protests and reading all this stuff about Black Lives Matter [...] They just switched green to black." The teachers that used this lesson plan decided to move beyond the script and further explore this connection that the students made with racial issues. In the class of the following teacher, for example, the students made blackout poetry which contributed to their development of critical empathy. As this teacher explains: 
They made a lot of connections with the Black Lives Matter protests that were happening at the time. And it really, I don't know, just fell into my hands. I didn't plan it, but it fell into my hands to be able to bring in some of the current affairs stuff. We did some blackout poetry, where the students actually wrote on a page, a whole lot of words that describe positive and negative that describe the "green children." And towards the end, they did a piece of blackout poetry based on all of the... we had like a big piece of paper on the board. And each time that somebody says something cruel about the [green children] or abused them in some way, or whatever, we added those words to the piece of paper. So by the end of the unit, we had a whole lot of different words to describe the green children and a lot of them were not very nice. So we typed all those up on a doc and did some blackout poetry. And it was so cool. Some of the poems that came out of that showed how it wasn't easy being green.

The "Superpower poetry fun" lesson plan also raised issues of exclusion and racism. One of the poems contained in this lesson plan talks about a Pacific woman in New Zealand who, despite being called "mophead," decides to stop hiding her hair and embrace her difference. As the following teacher explains, this poem not only helped the students of Pacific origin to relate to the experience of the woman in the poem, but also to connect this experience with the Black Lives Matter movement:

We did "Mophead" and that was really good. I think that was good because they were able to relate because they're mainly Pasifika, they were able to really relate to how she was feeling and to her hair. [...] Yeah, and then there were a few comments flying around about racism, about how racist it was. And then other comments that were made, and the children were pulling up other children about racism as well. So it actually opened up a whole conversation about racism, and it was just around the time when Black Lives Matter came up. So they were able to relate that whole issue back and forth to each other [...] It was very good. And the thing is, it was just from a poem.

\section{Contributing to Community Recuperation}

Another theme that emerged in the interviews refers to the use of the arts to contribute to community recovery. These contributions varied from students convincing their families to comply with Covid-19 related restrictions through to creating groups aimed at infusing hope in the future. An example of the latter was given by the teacher of a school with a majority of students coming from low socioeconomic backgrounds. This teacher used the "Teaspoon of light" lesson plan, an arts project about repairing broken dreams that starts with the first two lines of a spoken story: "A young girl wakes up to get ready to visit her grandmother. As she gets up, she trips and tears her cloth of dreams ...." The classroom discussions about possible ways to help the young girl who tore her dream cloth led the students to start a "dream weaver's company" with the goal of offering hope to the community. As part of this project but outside of the classroom, the students created videos advertising the company to convince other young people to join the drama group and to restore hope within their communities. As the teacher explained to us:

The students understood working between two worlds, one being that they were students at our school participating in a drama class and then as us as dream weavers working in the dream weaver's company. And so ... what they decided they wanted to do, in the end, was advertise their company because they wanted more students to come join drama and be dream weavers. But they said to me there's another level, we want people in our community to understand that there is hope. I hadn't said any of this to them deliberately, they came to these conclusions themselves. One, that they'd like more drama students working with them and two, that they'd like to offer some sort of hope to the community. So, in order to achieve both their aims simultaneously, they thought what they could do was create an advert, create a video advert, for their dream weaver's company.

\section{DISCUSSION}

This study delved into the perspectives of a group of New Zealand educators who used Te Rito Toi after the Covid-19 lockdown to explore the ways in which this resource helped them to engage their students in both individual and collective recovery. The following four themes arose from the analysis of the interviews with these teachers: 1) building relationships and a sense of belonging; 2) enhancing communication and empathy; 3) connecting with wider social issues; and 4) contributing to community recovery. These themes have shown the nuanced ways in which the artsbased pedagogical practices facilitated by Te Rito Toi interrelatedly promoted individual and collective recovery. In a sense the rito, the seedlings, were cared for and protected but so was the whole plant. And the arts were cared for, privileged as a way to return to school post crisis. Aligned with previous research literature (e.g., O'Connor, 2013a; O'Connor, 2013b; Fenner et al., 2018; Mutch and Latai, 2019), the findings of this study have highlighted the potentiality of the arts to promote both individual and collective well-being in post-crisis contexts. This potentiality took different forms in this study, from providing opportunities to share personal experiences and feelings with peers and build a sense of belonging through to making sense of the social world and contributing to community recuperation.

The educators that participated in this study rejected the idea that a return to "normal" was enough to meet the needs of children and teachers to coming to terms with how the world had changed since the pandemic. This response resonates with the experiences of other teachers and principals that refused the "going back to normal" approach when schools reopened after critical events (Mutch, 2014; Fletcher and Nicholas, 2016). For the participants, Te Rito Toi supported them to centre school life 
around well-being and the arts after lockdowns, similar to what other arts-based initiatives have provided to educators in other countries (e.g., Tam, 2020).

For the participants, the arts became the connective pathways for children and teachers to re-engage with each other and the issues that either lay underneath or surfaced as a result of lockdowns. Rather than focusing on a self-care, individualistic approach frequently found in well-being practices and discourses (Freebody et al., 2018; Walls et al., 2019), the pedagogical actions of the participants using Te Rito Toi revolved around building relationships amongst the students and with the wider community and society. These pedagogical actions fostered a culture of "inter-relational care" (Trnka and Trundle, 2014), in which listening to others, looking after other members of the community or concerning about issues that go beyond ourselves were an intrinsic part of the individual recovery and social reconnection. In this sense, Te Rito Toi embodied the practice of manaakitanga, a willingness to prioritise the rebuilding of community after children and teachers spent months in social isolation. As other literature has previously highlighted (e.g., Mutch, 2013; O'Connor, 2013a), this study shows how schools can act as caring communities in postdisaster contexts. This approach provided children with opportunities to build social cohesion, engage with wider social issues and participate in their communities as active citizens, highlighting the relational, social and civic dimensions of well-being (Dunphy, 2015). These forms of engagement not only align with the recognition of a children's right to contribute to the matters affecting their lives (United Nations Convention on the Rights of the Child, 1989), but also with other studies highlighting the importance of involving children in community recovery and the

\section{REFERENCES}

Anderson, W. A. (2005). Bringing Children into Focus on the Social Science Disaster Research Agenda. Int. J. Mass Emergencies Disasters 23, 159-175.

Bidwell, S. (2014). The Arts in Health: Evidence from International Evidence. Christchurch: Pegasus Health.

Burr, V. (2015). Social Constructionism. 3rd ed. London: Routledge/Taylor \& Francis.

Charmaz, K. (2014). Constructing Grounded Theory. 2nd ed. Thousand Oaks, CA: Sage.

Courtney, D., Watson, P., Battaglia, M., Mulsant, B. H., and Szatmari, P. (2020). COVID-19 Impacts on Child and Youth Anxiety and Depression: Challenges and Opportunities. Can. J. Psychiatry 65 (10), 688-691. doi:10.1177/0706743720935646

Cziboly, A., and Bethlenfalvy, A. (2020). Response to COVID-19 Zooming in on Online Process Drama. Res. Drama Educ. J. Appl. Theatre Perform. 25 (4), 645-651. doi:10.1080/13569783.2020.1816818

Davis, S., and Phillips, L. G. (2021). Teaching during COVID 19 Times-The Experiences of Drama and Performing Arts Teachers and the Human Dimensions of Learning. NJ(Drama Australia Journal) 44, 66-87. doi:10.1080/14452294.2021.1943838

Dunphy, K. (2015). “A Holistic Framework for Evaluation of Arts Engagement," in Making Culture Count: The Politics of Cultural Measurement. Editors L. MacDowall, M. Badham, E. Blomkamp, and K. Dunphy (London: Palgrave), 243-263. doi:10.1007/978-1-137-46458-3_16 restoration of collective hope for the future (Mutch, 2013; O'Connor, 2013a; Peek et al., 2016; Peek, 2008).

\section{DATA AVAILABILITY STATEMENT}

The original contributions presented in the study are included in the article/Supplementary Materials, further inquiries can be directed to the corresponding author.

\section{ETHICS STATEMENT}

The studies involving human participants were reviewed and approved by The University of Auckland Human Participants Ethics Committee (Ref. 2816). The patients/participants provided their written informed consent to participate in this study.

\section{AUTHOR CONTRIBUTIONS}

Conceptualization, PO'C; methodology, ME; formal analysis, $\mathrm{ME}$; writing-original draft preparation, $\mathrm{ME}$; writing-review and editing, $\mathrm{ME}$ and $\mathrm{PO}^{\prime} \mathrm{C}$; supervision, $\mathrm{PO} \mathrm{C}^{\prime} \mathrm{C}$; project administration, $\mathrm{PO} \mathrm{C}^{\prime}$; funding acquisition, $\mathrm{PO} \mathrm{C}^{\prime} \mathrm{C}$.

\section{FUNDING}

The Te Rito Toi project was funded by the NZ National Commission for UNESCO and The Chartwell Trust. The evaluation of the project was funded by Cognition Education Trust and The University of Auckland.

Fenner, P., Ryan, B., Latai, L., and Percival, S. (2018). Art Making and the Promotion of Wellbeing in Samoa - Participants' Lived Experience of a Recovery Oriented Intervention. Arts. Health. 10 (2), 124-137. doi:10.1080/ 17533015.2017.1334677

Fletcher, J., and Nicholas, K. (2016). What Can School Principals Do to Support Students and Their Learning during and after Natural Disasters? Educ. Rev. 68 (3), 358-374. doi:10.1080/00131911.2015.1114467

Freebody, K., Mullen, M., Walls, A., and O'Connor, P. (2018). Who Is Responsible? Neoliberal Discourses of Well-Being in Australia and New Zealand. NJ(Australian Drama Journal) 42, 139-153. doi:10.1080/ 14452294.2019.1572432

Gallagher, K., Balt, C., Cardwell, N., and Charlebois, B. (2020). Response to COVID-19 - Losing and Finding One Another in Drama: Personal Geographies, Digital Spaces and New Intimacies. Res. Drama Educ. J. Appl. Theatre Perform. 25 (4), 638-644. doi:10.1080/13569783.2020.1816817

Ghosh, R., Dubey, M. J., Chatterjee, S., and Dubey, S. (2020). Impact of COVID -19 on Children: Special Focus on the Psychosocial Aspect. Minerva Pediatr. 72 (3), 226-235. doi:10.23736/S0026-4946.20.05887-9

Gibbs, L., Mutch, O., O'Connor, P., and MacDougall, C. (2013). Research with, by, for and About Children: Lessons from Disaster Contexts. Global Studies of Childhood 3 (2), 129-141. doi:10.2304/gsch.2013.3.2.129

Gibbs, L., MacDougall, C., and Mutch, C. (2017). "Child Citizenship in Disaster Risk and Affected Environments," in Disaster Resilience: An Integrated Approach. 2nd ed. Editors D. Paton and D. Johnston. Springfield, Ill, USA: Charles C Thomas 
Golberstein, E., Wen, H., and Miller, B. F. (2020). Coronavirus Disease 2019 (COVID-19) and Mental Health for Children and Adolescents. JAMA Pediatr. 174, 819. doi:10.1001/jamapediatrics.2020.1456

Hargreaves, A., and Fullan, M. (2020). Professional Capital after the Pandemic: Revisiting and Revising Classic Understandings of Teachers' Work. Jpcc 5, 327-336. doi:10.1108/JPCC-06-2020-0039

Huss, E., Kaufman, R., Avgar, A., and Shuker, E. (2016). Arts as a Vehicle for Community Building and post-disaster Development. Disasters 40 (20), 284-303. doi:10.1111/disa.12143

Labrague, L. J., and Ballad, C. A. (2020). Lockdown Fatigue Among College Students during the Covid-19 Pandemic: Predictive Role of Personal Resilience, Coping Behaviours, and Health. MedRxiv, 1-23. doi:10.1101/ 2020.10.18.20213942

Li, S. H., Beames, J. R., Newby, J. M., Maston, K., Christensen, H., and WernerSeidler, A. (2020). The Impact of COVID-19 on the Lives and Mental Health of Australian Adolescents. MedRxiv, 1-30. doi:10.1101/ 2020.09.07.20190124

Martin, A. J., Mansour, M., Anderson, M., Gibson, R., Liem, G. A. D., and Sudmalis, D. (2013). The Role of Arts Participation in Students' Academic and Nonacademic Outcomes: A Longitudinal Study of School, home, and Community Factors. J. Educ. Psychol. 105 (3), 709-727. doi:10.1037/ a003279510.1037/a0032795

Milner, M., and Ngata, R. (2021). The Indigenous Custom behind New Zealand's strong Covid-19 Response. The Washington Post, March 11. Available at: https://www.washingtonpost.com/opinions/2021/03/11/ new-zealand-covid-19-maori-indigenous-manaakitanga/. (Accessed on September 22, 2021).

Mitchell, G. V. (2015). What I See in My Dreams": Using Art to Heal Invisible Wounds. Nat. Hazards Observer XXXIX (6), 14-20.

Murphy, C. (2014). Post-disaster Group Art Therapy Treatment for Children. A Master of Arts Dissertation. USA: Loyola Marymount University and Loyola Law School.

Mutch, C. (2013). Sailing Through a River of Emotions: Capturing Children's Earthquake Stories. Dis. Prev. and Management 22 (5), 445-455. doi:10.1108/ DPM-10-2013-0174

Mutch, C. (2020a). Crisis Leadership: Evaluating Our Leadership Approaches in the Time of COVID-19. Em 6, 1-24. doi:10.18296/em.0058

Mutch, C. (2020b). How Might Research on Schools' Responses to Earlier Crises Help Us in the COVID-19 Recovery Process? SET: Res. Inf. Teach. 2, 3-10. doi:10.18296/set.0169

Mutch, C., and Latai, L. (2019). Creativity beyond the Formal Curriculum: ArtsBased Interventions in post-disaster Trauma Settings. Pastoral Care Educ. 37 (3), 230-256. doi:10.1080/02643944.2019.1642948

Mutch, C. (2014). The Role of Schools in Disaster Preparedness, Response and Recovery: what Can We Learn from the Literature? Pastoral Care Educ. 32 (1), 5-22. doi:10.1080/02643944.2014.880123

Mutch, C., Yates, S., and Hu, C. (2015). Gently, Gently: A School-university Participatory Research Partnership in a post-disaster Setting. Gateways 8 (1), 79-99. doi:10.5130/ijcre.v8i1.4161

Mutch, C., and Estellés, M. (2015). Exploring Youth Citizenship during the Covid19 Lockdowns in New Zealand. Citizenship Teaching and Learning 16 (3). doi:10.5130/ijcre.v8i1.4161

OECD (2020). The Impact of COVID-19 on Student Equity and Inclusion: Supporting Vulnerable Students during School Closures and School Reopenings. Paris: OECD. Available at: https://read.oecd-ilibrary.org/view/? ref=434_434914-59wd7ekj29\&title=The-impact-of-COVID-19-on-studentequity-and-inclusion.

O'Connor, P, P., and Estellés, M. (2021). Seeding Possibilities with the Arts: Te Rito Toi in Schools during Covid-19 (Research Report). Auckland, New Zealand: The University of Auckland.

O'Connor, P, P. (2013a). Pedagogy of Love and Care: Shaken Schools Respond. Dis. Prev. and Management 22 (5), 425-433.

O'Connor, P, P. (2013b). "TIE: The pedagogic as the aesthetic in a crumbling world," in Learning Through Theatre: The Changing Face of Theatre in
Education. Editors A. Jackson and C. Vine (London and New York: Routledge), 305-320.

O'Connor, P, P., and Takahashi, N. (2014). From Caring About to Caring for: Case Studies of New Zealand and Japanese Schools Post Disaster. Pastoral Care Educ. 32 (1), 42-53. doi:10.1080/02643944.2013.875584

Ozamiz-Etxebarria, N., Berasategi Santxo, N., Idoiaga Mondragon, N., and Dosil Santamaría, M. (2021). The Psychological State of Teachers during the COVID19 Crisis: The challenge of Returning to Face-To-Face Teaching. Front. Psychol. 11, 3861. doi:10.3389/fpsyg.2020.620718

Peek, L. (2008). Children and Disasters: Understanding Vulnerability, Developing Capacities, and Promoting Resilience - an Introduction. Child. Youth Environments 18 (1), 1-29.

Peek, L., Tobin-Gurley, J., Cox, R. S., Scannell, L., Fletcher, S., and Heykeep, C. (2016). Engaging Youth in post-disaster Research: Lessons Learned from a Creative Methods Approach. Gateways: Int. J. Community Res. Engagement 9 (1), 89-112. doi:10.5130/ijcre.v9i1.4875

Rio Poncela, A. M., Romero Gutierrez, L., Bermúdez, D. D., and Estellés, M. (2021). A Labour of Love? The Invisible Work of Caring Teachers During Covid-19. Pastoral Care Educ., 1-17. doi:10.1080/02643944.2021.1938646

Shanahan, L., Steinhoff, A., Bechtiger, L., Murray, A. L., Nivette, A., Hepp, U., et al. (2020). Emotional Distress in Young Adults during the COVID-19 Pandemic: Evidence of Risk and Resilience from a Longitudinal Cohort Study. Psychol. Med., 1-10. doi:10.1017/S003329172000241X

Skregelid, L. (2021). Zoom in on Dry Joy-Dissensus, Agonism and Democracy in Art Education. Educ. Sci. 11, 28. doi:10.3390/educsci1 1010028

Tam, P.-C. (2020). Response to COVID-19 'Now I Send You the Rays of the Sun': a Drama Project to Rebuild post-COVID-19 Resilience for Teachers and Children in Hong Kong. Res. Drama Educ. J. Appl. Theatre Perform. 25 (4), 631-637. doi:10.1080/13569783.2020.1816816

Trnka, S., and Trundle, C. (2014). Competing Responsibilities: Moving beyond Neoliberal Responsibilisation. Anthropological Forum 24 (2), 136-153. doi:10.1080/00664677.2013.879051

United Nations Convention on the Rights of the Child. (1989). G.A. Res. 44/25, Annex, 44 U.N. GAOR Supp. (No. 49) at 167, U.N. Doc. A/44/49 (1989), Entered into Force September 2 1990. Available at:/C/93/Add.5 (Accessed 16 July 2003.

van Lieshout, K. (2020). New Zealand: Te Rito Toi (Reconnecting Students through the Arts). Paris: OECD Publishing.

Warrington, C., and Larkins, C. (2019). Children at the centre of Safety: Challenging the False Juxtaposition of protection and Participation. Jcs 14 (3), 133-142. doi:10.1108/JCS-09-2019-055

Walls, A., Deane, K. L., and O'Connor, P. (2016). Looking for the Blue, the Yellow, all the Colours of the Rainbow: The Value of Participatory Arts for Young People in Social Work Practice. Aotearoa New Zealand Social Work 28 (4), 67-79.

Walls, A., Mullen, M., McTaggart, S., and O'Connor, P. (2019). Creative Practice for Youth Wellbeing in Aotearoa New Zealand (Research report). Auckland: The University of Auckland.

Conflict of Interest: The authors declare that the research was conducted in the absence of any commercial or financial relationships that could be construed as a potential conflict of interest.

Publisher's Note: All claims expressed in this article are solely those of the authors and do not necessarily represent those of their affiliated organizations, or those of the publisher, the editors and the reviewers. Any product that may be evaluated in this article, or claim that may be made by its manufacturer, is not guaranteed or endorsed by the publisher.

Copyright (0) 2021 O'Connor and Estellés. This is an open-access article distributed under the terms of the Creative Commons Attribution License (CC BY). The use, distribution or reproduction in other forums is permitted, provided the original author(s) and the copyright owner(s) are credited and that the original publication in this journal is cited, in accordance with accepted academic practice. No use, distribution or reproduction is permitted which does not comply with these terms. 